\title{
KEBIJAKAN FORMULASI SANKSI PIDANA DALAM PENANGGULANGAN TINDAK PIDANA SIBER BERDASARKAN UNDANG-UNDANG INFORMASI DAN TRANSAKSI ELEKTRONIK
}

\author{
Mochamad Sahid \\ Dosen Sekolah Tinggi Hukum Garut \\ e-mail: Muhammadsyahid2409@gmail.com
}

\begin{abstract}
Abstrak-Perkembangan masyarakat tidak dapat dilepaskan dari perkembangan teknologi. Perkembangan teknologi informasi selain membawa hal positif juga membawa hal negatif kepada masyarakat. Cybercrime merupakan jenis kejahatan baru yang lahir karena pesatnya perkembangan teknologi informasi dan komunikasi. Di Indonesia masih banyak sekali kasus-kasus yang menyangkut mengenai cybercrime yang sulit untuk diselesaikan. Kebijakan formulasi undang-undang informasi dan transaksi elektronik saat ini masih mempunyai kelemahan, karena belum memperlihatkan efektivitas dalam menanggulangi tindak pidana siber, meskipun pada dasarnya sangat sulit untuk menentukan keefektifan tindak pidana siber, namun dengan semakin meningkatnya tindak pidana siber berdasarkan data yang ada saat ini, untuk sementara dapat diindikasikan belum tercapai apa yang menjadi tujuan dari pembentuk undang-undang.
\end{abstract}

\section{Kata Kunci: Kebijakan, Formulasi, Sanksi Pidana, Tindak Pidana Siber.}

Abstract-Public development cannot be separated from technology development. The development of information and technology, beside brings positive impacts, it also carries negative impacts to the public. Cyber crime is the type of a new crime because of the rapid developments in the technology information and communication. In Indonesia, there still many cases about cybercrime that hard to be solved. The policy of formulation legislation and information and electronic transaction still have a weakness, because it doesn't show the effectiveness of countermeasuring a cybercrime, although it's very difficult to determine the effectivensess of cyber crime itself. With the cybercrime keeps increasing based on current data today, we can indicate that we haven't accomplished the purpose of what legislation is made.

Keywords: Policy, Formulation, Criminal Sanction, Cyber Crime.

\section{A. PENDAHULUAN}

Teknologi komputer telah memunculkan sesuatu yang baru di dalam kehidupan saat ini, yaitu internet. Internet telah menjadi sangat penting bagi manusia di seluruh dunia. Eksistensi dari beberapa jenis bisnis justru tidak mungkin berlangsung tanpa adanya internet. Manusia menjadi makin nyaman dalam menyelenggarakan kegiatan pribadinya sehari-hari dan mereka yang telah terbiasa dengan internet menjadi tidak nyaman apabila aksesnya kepada internet terganggu (Sutan Remy Syahdeini, 2009:2). 
Dalam konsideran menimbang Undang-Undang Nomor 11 Tahun 2008 disebutkan bahwa perkembangan dan kemajuan Teknologi Informasi yang demikian pesat telah menyebabkan perubahan kegiatan kehidupan manusia dalam berbagai bidang yang secara langsung telah mempengaruhi lahirnya bentukbentuk perbuatan hukum baru.

Teknologi informasi dan komunikasi telah mengubah perilaku masyarakat dan peradaban manusia secara global. Di samping itu, perkembangan teknologi dan informasi telah menyebabkan dunia menjadi tanpa batas (borderless)dan menyebabkan perubahan sosial yang secara signifikan berlangsung demikian cepat. Teknologi informasi saat ini menjadi pedang bermata dua, karena selain memberikan kontribusi bagi peningkatan kesejahteraan, kemajuan dan peradaban manusia, sekaligus menjadi sarana efektif perbuatan melawan hokum

(H.

Ahmad M. Ramli, 2004:1).

Di samping menciptakan berbagai peluang baru dalam kehidupan masyarakat, internet juga sekaligus menciptakan peluang- peluang baru bagi kejahatan. Di dunia virtual orang melakukan berbagai perbuatan jahat (kejahatan) yang justru tidak dapat dilakukan di dunia nyata. Kejahatan tersebut dilakukan dengan menggunakan computer sebagai sarana perbuatannya (Sutan Remy Syahdeini, 2009:8).

Kejahatan dalam bidang telematika ini merupakan sisi negatif dari kemajuan teknologi yang mempunyai dampak yang sangat luas bagi seluruh bidang kehidupan modern saat ini. Beberapa bentuk kejahatan telematika (Dini Dewi Heniarti dalam Edi Setiadi, 2004:2), antara lain:

1. Penggunaan kartu kredit milik orang lain.

2. Transaksi perbankan.

3. Pemanfaatan kode rahasia (PIN) milik orang lain untuk penarikan uang tunai dari ATM.

4. Perikatan atau kontrak elektronik.

5. Penggunaan domain milik orang lain yang melanggar ha katas kekayaan intelektual.

6. Membuat, menyediakan, atau mengirimkan atau menghapus data komputer yang mengakibatkan terganggunya fungsi sistem.

7. Membuat, menyediakan, atau mengirimkan atau menghapus data elektronik yang mengakibatkan kerugian ekonomi bagi orang lain.

8. Mengakses jaringan computer dengan maksud mencuri data (hacker). 
Dari berbagai contoh di atas dapat disimpulkan bahwa kejahatan yang dilakukan merupakan tindak pidana yang selama ini telah di kenal seperti pencurian, pemalsuan, kejahatan kesusilaan, penggunaan hak milik orang lain tanpa izin, akan tetapi pelaksanaan tindak pidana dilakukan dengan menggunakan jaringan da atau jasa telekomunikasi (Dini Dewi Heniarti dalam Edi Setiadi, 2004:3).

Wakil Direktur Tindak Pidana Ekonomi Khusus Bareskrim Kepolisian Indonesia, Komisaris Besar Polisi Agung Setya pada Selasa 25 Agustus 2015 mengungkapka bahwa serangan kejahatan dalam jaringan di Indonesia oleh para peretas atau hackers sejak 2012 sampai April 2015, Subdit IT/Cybercrime telah menangkap 497 orang tersangka kasus kejahatan di dunia maya. Dari jumlah itu, sebanyak 389 orang warga negara asing, dan 108 WNI. Ia juga mengatakan sedang mewaspadai kejahatan IT model terbaru, yaitu peretasan mobil mewah yang bisa diterobos dengan jaringan teknologi (Majalah Tempo).
Selain dari itu Direskrimsus Polda Jabar Kombes Pol Wirdhan Deny Mapolda Jabar mengungkapkan bahwa kasus tindak pidana siber dari tahun 2013 sampai 2015 mengalami peningkatan. Tahun 2013 sebanyak 57, tahun 2014 sebanyak 193, tahun 2015 sebanyak 348, dan tahun 2016 dari bulan Januari sampai Juni ada 188 kasus. Pada tahun 2015 dari 188 kasus POLDA JABAR hanya mengungkap 77 kasus cybercrime. Jenis perkaranya didominasi penghinaan dan pencemaran nama baik melalui media sosial. Ada 188 kasus cybercrime yang ditangani. Jumlah diselesaikan 77 kasus dengan 77 tersangka, semuanya sudah dilimpahkan ke pengadilan. Ragam modus kejahatan cyber diungkap itu antara lain soal pornografi atau kesusilaan, pencemaran nama baik, pemerasan, penipuan, sebar rasa kebencian dan pencurian identitas dalam sistem elektronik. Kebanyakannya kasus penghinaan dan pencemaran nama baik. Mayoritasnya terjadi di media sosial Facebook (DitReskrimSus POLDA JABAR). 
Indonesia sendiri mempunyai undang-undang utama yang mengatur tentang informasi dan transaksi elektronik yaitu Undang-Undang Nomor 11 Tahun 2008 tentang Informasi dan Transaksi Elektronik yang kemudian direvisi menjadi Undag-Undang Nomor 19 Tahun 2016. Dalam Undang-Undang ITE ini dimuat ketentuan-ketentuan mengenai larangan-larangan melakukan perbuatan-perbuatan tertentu yang diancam dengan sanski pidana bagi pelakunya. Dalam hal ini undangundang ITE tersebut menetapkan beberapa perbuatan yang dikriminalisasikan sebagai tindak pidana komputer dengan sanksisanksinya.

\section{Barda Nawawi Arief} menyatakan, berbagai langkah kebijakan penganggulangan tindak pidana khususnya berkaitan dengan tindak pidana siber dengan mengeluarkan berbagai produk perundang-undangan yang menyangkut pemberantasan tindak pidana siber menunjukkan bahwa strategi kebijakan lebih terfokus pada upaya melakukan pembaruan undangundang. Upaya melakukan pembaruan undang-undang merupakan langkah yang sepatutunya dilakukan. Tetapi karena masalah tindak pidana siber mengandung kompleksitas masalah, maka seyogyanya ditempuh pendekatan integral. Tidak hanya melakukan law reform, tetapi juga disertai dengan social, economic, political, cultural, moral and administrative reform (Barda Nawawi Arief, 2003:66).

Pemberantasan suatu tindak pidana dengan menggunakan sanksi pidana merupakan cara yang paling banyak dilakukan. Sampai saat ini pun pengenaan sanksi pidana untuk kasus tindak pidana siber dipandang sebagai salah satu cara yang bisa diharapkan bisa memberantas tindak pidana siber.

Dalam Rancangan KUHP tahun 2015 ketentuan menganai sistem pemidanaan sudah mengalami pembaharuan yakni dari jenis dan ukuran penjatuhan pidananya. Untuk jenis-jenis pidana menganut double track system dalam hal ini sudah mengakomodir pidana dan tindakan. Lalu untuk ukuran pidananya sudah mengakomodir pidana minimum dan pidana maksimum. Maka dari itu pola 
pemidanaan yang ada pada UndangUndang ITE saat ini harus disesuaikan dengan pola pemidanaan yang ada dalam konsep Rancangan KUHP yang baru ini.

Efek suatu sanksi merupakan masalah empiris, oleh karena manusia mempunyai persepsi yang tidak sama mengenai sanksi-sanski tersebut. Pihak-pihak lainnya menganggap bahwa penyebab utama adanya dan meningkat kriminalitas adalah terlalu ringannya sanksi atau hukuman yang dijatuhkan. Para pihak yang secara cermat memperhitungkan akibatakibat perilakunya, mempunyai anggapan kuat bahwa sanksi atau hukuman yang ringan tidak akan terlalu merugikannya, sehinggar resiko yang kelak harus ditanggungnya tidak akan terlalu berat (Soerjono Soekanto, 1985:89).

Berdasarkan uraian diatas, maka penulis membatasi permasalahan yang akan dibahas yaitu bagaimana kebijakan formulasi sanksi pidana dalam penanggulangan tindak pidana siber berdasarkan Undang-Undang Nomor 11 Tahun 2008 tentang informasi dan transaksi elektronik juncto Undang-Undang
Nomor 19 Tahun 2016? Dan bagaimana kebijakan formulasi sanksi pidana Undang-Undang Nomor 19 Tahun 2016 di masa yang akan datang sehubungan dengan perkembangan kejahatan tindak pidana siber dalam masyarakat?

\section{B. HASIL DAN PEMBAHASAN}

1. Kebijakan Formulasi Sanksi Pidana Dalam

Penanggulangan Tindak Pidana Siber Berdasarkan Undang-Undang Informasi Dan Transaksi Elektronik

Kebijakan Formulasi/legislasi adalah proses pembuatan peraturanperundang-undangan yang dilakukan oleh pembuat undang-undang (pemerintah bersama-sama dengan Dewan Perwakilan Rakyat/DPR). Kedua badan/institusi inilah yang berwenang membuat peraturan hukum, yaitu melalui proses mewujudkan harapan hukum dalam realita. Karena itu, setiap aturan hukum yang dibuat hendaknya dapat menjangkau setiap kebutuhan dan kejadian dalam masyarakat, seperti halnya Chambliss dan Seidman mengungkapkan bahwa proses 
pembuatan peraturan tidak hanya ditentukan oleh badan pembuat peraturan saja, tetapi juga ditentukan oleh peranan dan kekuatan sosial dan pribadi, termasuk tatanan kebiasaan dan kesusilaan (Henny Nuraeny, 2013:279).

Tahap kebijakan formulasi/ legislasi adalah tahap yang strategis, karena pada tahap ini akan dihasilkan suatu peraturan hukum yang akan menjadi pedoman pada tahap-tahap berikutnya dalam proses kebijakan hukum pidana. Produk legislatif yang dinamakan undang-undang ini dalam tataran kebijakan hukum merupakan tataran formulasi, dan posisinya berada dalam tataran abstrak (berupa peratruan/undang-undang), artinya undang-undang ini akan mempunyai makna, apabila diberlakukan dalam realitas. Untuk itu, agar undangundang ini dapat terealisai dalam masyarakat, diperlukan badan-badan yang dapat melaksanakannya yang dalam ilmu hukum/ilmu politik dinamakan badan eksekutif. Sedangkan bada yang bertugas menrapkan atau mengefektifkan peraturan perundang-undangan dinamakan badan yudisial/badan yudikatif yang mandiri dan netral, serta bebas campur tangan badan lainnya (Heny Nuraeny, 2013:298).

Selain itu masalah kebijakan formulasi juga berhubungan dengan masalah penitensier, yang merupakan bagian terpenting dari kebijakan pemidanaan (sentencing policy), yang menurut Herbertt L. Parker merupakan salah satu masalah kontroversial dalam hukum pidana (Henny Nuraeny, 2013:298).

Menurut Barda Nawawi Arief, konsepsi kebijakan penaggulangan hukum pidana yang integral mengandung keonsekuensi bahwa segala usaha yang rasional untuk menanggulangi kejahatan, harus mrupakan satu kesatuan yang terpadu. Ini berarti kebijakan penanggulangan hukum pidana harus dipadukan antara penal dan non penal, yang mencakup bidang yang sangat luas dalam bidang kebijakan sosial atau pembangunan nasional (Barda Nawawi Arief, 2000:34).

Kebijakan Penegakan hukum pidana merupakan rangkaian proses yang terdiri dari tiga tahap (Russel Butarbutar, 2016:11), yaitu: 
a. Tahap

legislatif/formulatif

menetapkan atau merumuskan perbuatan apa yang dapat dipidana dan sanksi apa yang dikenakan oleh badan pembuat undangundang.

b. Tahap kebijakan yudikatif/aplikatif yaitu menerapkan hukum pidana oleh aparat penegak hukum, mulai dari kepolisisan, kejaksaan dan pengadilan.

c. Kebijakan eksekutif/administratif, yaitu melaksanakan hukum pidana secara konkret oleh aparat pelaksana pidana.

Kebijakan formulasi dapat berupa kriminalisasi/pembaruan hukum dengan menciptakan aturan baru, atau dapat berupa regulasi yang merubah dan menambah/merievisi peraturan lama. Secara umum, pembaruan hukum pidana dapat dilakukan untuk seluruh bagian hukum pidana secara global/menyeluruh, ataupun secara parsial/bagian baik hukum pidana maupun hukum pidana khsusus. Salah satu bagian hukum pidana khusus yang merupakan hasil formulasi di bidang hukum pidana adalah tindak pidana siber yang diatur oleh Undang-Undang Informasi dan Transaksi elektronik.

Kebijakan formulasi dengan membuat peraturan hukum ditujukan untuk dilaksanakan, pelaksanaan hukum tidak dapat dipisahkan dari masyarakat, karena itu penilaian terhadap bekerja dan berlakunya hukum sangat bergantung pada lingkungan dan struktur sosial masyarakat dimana hukum tersebut diberlakukan (Henny Nuraeny, 2013:161).

Evaluasi terhadap kebijakan di dunia mayantara tetap diperlukan sekiranya ada kelemahan kebijakan formulasi dalam perundang-undangan tersebut. Menurut Barda Nawawi Arief Evaluasi atau kajian ulang ini perlu dilakukan, karena ada keterkaitan erat antara kebijakan formulasi perundang-undangan (legaslative policy) dengan kebijakan penegakan hukum (law enforcement policy) dan kebijakan pemberantasan/ penanggulangan kejahatan (criminal policy). Kelemahan kebijakan formulasi hukum pidana, akan berpengaruh pada kebijakan penegakan hukum pidana dan kebijakan penanggulangan kejahatan (Philemon Ginting, 2008:60).

Di dalam Undang-Undang Nomor 11 Tahun 2008 Tentang Informasi dan Transaksi Elektronik 
yang telah direvisi menjadi UndangUndang Nomor 19 Tahun 2016 Tentang Perubahan Atas UndangUndang Nomor 11 Tahun 2008 Tentang Informasi dan Transaksi Elektronik, telah diatur sanksi pidana dalam ketentuan Bab XI yang terdiri atas Pasal 45 sampai dengan Pasal 52 terhadap perbuatan yang diatur dalam ketentuan Bab VII sebagai perbuatan-perbuatan yang dilarang beserta masing-masing sanksi pidananya. Perbuatan-perbuatan yang dilarang dan bersanksi pidana itu merupakan tindak-tindak pidana komputer Indoensia. Tindak-tindak pidana komputer yang telah diatur oleh Undang-Undang ITE tersebut.

Jenis-jenis kejahatan yang diatur dalam Undang-Undang Nomor 11 Tahun 2008 jo. Undang-Undang 19 Tahun 2016:

a. Pornografi (Pasal 27 ayat (1));

b. Perjudian online (Pasal 27 ayat (2));

c. Penghinaan dan atau pencemaran nama baik (Pasal 27 ayat (3));

d. Pemerasan dan atau pengancaman (Pasal 27 ayat (4));

e. Penyebaran berita bohong dan penyesatan (Pasal 28 ayat (1));

f. Penyebaran informasi yang bermuatan SARA (Pasal 28 ayat (2)); g. Pengiriman informasi bermuatan ancaman kekearasan atau menakut-nakuti (Pasal 29);

h. Pembobolan komputer (Pasal 30 ayat (1), (2), dan (3));

i. Intersepsi atau penyadapan atas informasi elektronik dan/atau dokumen elektronik yang disimpan dalam komputer dan atau/atau sistem elektronik (Pasal 31 ayat (1) dan (2));

j. Mengusik informasi/dokumen elektronik (Pasal 32 ayat (1));

k. Memindahkan atau mentransfer informasi/dokumen elektronik (Pasal 32 ayat (2));

1. Tindak pidana komputer terhadap sistem elektronik (Pasal 33);

m. Tindak pidana komputer yang menyangkut perangkat keras dan perangkat lunak komputer (Pasal 34 ayat (1));

n. Tindak pidana komputer yang merugikan orang lain (Pasal 36);

o. Tindak pidana komputer yang dilakukan di luar wilayah Indonesia (Pasal 37);

p. Tindak pidana komputer yang dilakukan oleh korporasi (Pasal 52 ayat (4));

q. Membobol komputer dan/atau sistem elektronik pemerintah (Pasal 52 ayat (2)).

$$
\text { Rumusan sanksi pidana }
$$

terhadap kejahatan atau tindak pidana siber sebagaimana diatur dalam ketentuan yang telah disebutkan di atas pada dasarnya menerapkan sanksi pidana pokok Pasal 10 KUHP berupa penjara dan/atau pidana denda yang merupakan sanksi pidana yang 
bersifat kumulatif (gabungan)- juga dikenakan sanksi pidana denda. alternatif, dengan mengutamakan Namun jika sanksi denda tidak dapat penerapan sanksi pidana terlebih dibayar dengan subsider Pasal 30 dahulu dan kemudian diikuti dengan KUHP maka sangat merugikan sanksi pidana denda secara kumulatifalternatif. Formulasi penerapan sanksi negara.

Berdasarkan hasil penelitian pidana seperti ini menunjukkan didapatkan jumlah data pelaku tindak bahwa pelaku tindak pidana siber bisa dikenakan sanksi pidana ganda yang cukup berat, yaitu diterapkan sanksi pidana penjara dan/atau sekaligus pidana dari Direktorat Kriminal Khusus Kepolisian Daerah Jaawa Barat, jumlah pelaku tindak pidana siber adalah sebagai berikut:

Tabel 1

Data Tindak Pidana Siber Yang Terjadi Di Wilayah Kepolisian Daerah Jawa Barat

\begin{tabular}{|c|c|c|c|c|c|}
\hline Tahun & $\begin{array}{c}\text { Tahun } \\
\mathbf{2 0 1 3}\end{array}$ & $\begin{array}{c}\text { Tahun } \\
\mathbf{2 0 1 4}\end{array}$ & $\begin{array}{c}\text { Tahun } \\
\mathbf{2 0 1 5}\end{array}$ & $\begin{array}{c}\text { Tahun } \\
\mathbf{2 0 1 6}\end{array}$ & Jumlah \\
\hline Jumlah Kasus & 57 & 193 & 348 & 188 & 786 \\
\hline Penyelesaian & 8 & 73 & 183 & 12 & 276 \\
\hline Sisa & 49 & 120 & 165 & 176 & 501 \\
\hline
\end{tabular}

Berdasarkan data di atas kasus tindak pidana siber dari tahun 20132015 mengalami peningkatan. Walupun pada tahun 2016 cenderung meneurun, namun jumlah kasusnya masih tetap banyak. Pada tahun 2013 jumlah kasus yang masuk ke POLDA JABAR sebanyak 57 kasus, yang berhasil diselesaikan 8 kasus, dan yang belum terselesaikan sebanyak 49 kasus. Tahun 2014 sebanyak 193 kasus, yang berhasil diselesaikan 73 kasus, yang belum terselesaikan sebanyak 120. Tahun 2015 sebanyak 348 kasus, yang berhasil diselesaikan 183 kasus, yang belum terselesaikan sebanyak 176 kasus. Sedangkan Tahun 2016 jumlah kasus sebanyak 188 kasus, yang berhasil diselesaikan 12 kasus, dan yang belum terselesaikan sebanyak 348 kasus. Apabila dilihat dari jumlah keseluruhan dari tahun 2013-2016 sebanyak 786 kasus, yang berhasil diselesaikan 276 kasus, dan yang 
belum terselesaikan sebanyak 501. diselesaikan tidak semuanya yang Namun dari semua kasus yang sampai P-21.

Tabel 2

Tabulasi Penanganan Tindak Pidana Siber Oleh Pengadilan Negeri Bandung Yang Telah Mendapat Putusan

\begin{tabular}{|l|c|c|c|c|}
\hline \multirow{2}{*}{ Jenis Perkara } & \multicolumn{4}{|c|}{ Tahun } \\
\cline { 2 - 5 } & 2013 & 2014 & 2015 & 2016 \\
\hline $\begin{array}{l}\text { Pencurian } \\
\text { Kenggunakan Kartu }\end{array}$ & 2 & 0 & 1 & 1 \\
\hline $\begin{array}{l}\text { Pemalsuan Kartu } \\
\text { Kredit }\end{array}$ & 2 & 1 & 1 & 0 \\
\hline $\begin{array}{l}\text { Penipuan Dengan } \\
\text { Menggunakan Kartu } \\
\text { Kredit }\end{array}$ & 1 & 0 & 0 & 0 \\
\hline $\begin{array}{l}\text { Penipuan Melalui } \\
\text { Internet }\end{array}$ & 0 & 5 & 3 & 5 \\
\hline $\begin{array}{l}\text { Penggelapan } \\
\text { menggunakan kartu } \\
\text { kredit orang lain }\end{array}$ & 0 & 1 & 0 & 0 \\
\hline $\begin{array}{l}\text { Perjudian melalui } \\
\text { internet }\end{array}$ & 0 & 1 & 1 & 0 \\
\hline Pornografi & 0 & 0 & 2 & 0 \\
\hline $\begin{array}{l}\text { Pencurian Kartu } \\
\text { Kredit }\end{array}$ & 0 & 0 & 0 & 1 \\
\hline Jumlah & 5 & 8 & 8 & 7 \\
\hline
\end{tabular}

Jumlah kasus yang berhasil ditangani sampai mendapat putusan dari tahun 2013 sampai 2016 adalah 26 kasus. Sisa dari keseluruhan jumlah sebanyak 501 ada yang tidak ditindak lanjuti, sedang dalam proses penyelidikan, dan diberhentikan prosesnya. Rata-rata tindak pidana siber dari 26 kasus tersebut antara lain: pencurian, penipuan, penggelapan, pemalsuan, pornografi dan perjudian, namun yang sering terjadi adalah kasus penipuan.

$$
\text { Berdasarkan }
$$

penelitian lapangan di Markas Kepolisian Daerah Jawa Barat, jumlah personel aparat penegak hukum yang mempunyai kemampuan khsusus di bidang Informasi dan Transaksi sangat sedikit, yaitu berjumlah 6 orang. Dalam setiap penyelidikan maupun penyidikan aparat penegak hukum di bidang Informasi dan 
Transaki Elektronik mengalami hambatan dengan jumlah aparat penegak hukum yang sedikit sementara jumlah laporan yang masuk ke Polda Jawa Barat sangat banyak.

Dalam menangani kasus tindak pidana siber Kepolisian Daerah Jawa Barat tidak mempunyai sarana yang cukup menunjang untuk melakukan penyelidikan. Direktorat Kriminal Khusus tidak mempunyai alat untuk menyadap pelaku tindak pidana siber, serta dalam melaksanakan tugasnya harus berhubunga dengan Subdit IT bidang Siber di Markas Besar Kepolisian Republik Indonesia sehingga butuh waktu yang cukup lama untuk melakukan penyelidikan. Selain dari itu, dalam mengungkap kasus tindak pidana siber, karena belum mempunyai alat untuk menyadapa posisi pelaku tindak pidana siber. Dierktorat Kriminal Khusus bekerjasama dengan Lembaga Industri lainnya. Dalam hal ini operator penyedia layanan. Seperti P.T Telkomsel, Indosat, dan lain-lain.

Kemudian dalam hal penganan kasus dibutuhkan dana yang cukup besar juga. Direktorat Kriminal

\begin{abstract}
Khusus Polda Jawa Barat mempunyai anggaran yang terbatas dalam setiap menyelidiki kasus tindak pidana siber. Sehingga kasus yang masuk, tidak semuanya diselesaikan karena tebentur dengan anggaran yang minim dalam setiap kasusnya. Anggaran yang ada sedikit, sementara jumlah kasus tindak pidana siber banyak.
\end{abstract}

\section{Kebijakan Formulasi Sanksi} Pidana Undang-Undang Nomor 19 Tahun 2016 Di Masa Yang Akan Datang Sehubungan Dengan

Perkembangan Kejahatan Tindak Pidana Siber Dalam Masyarakat

Dilihat dari sudut penetapan sanksi, formulasi sanksi dalam Undang-Undang Informasi dan Transaksi Elektronik yang telah disesuaikan dengan bobot delik dan kualifikasinya adalah sesuai dengan hukum pidana modern yang berorientasi kepada perbuatan dan pelaku. Hal ini sejalan dengan ide filsafat aliran modern let the punishment fit the criminal. Namun dalam memformulasikan snaksi 
tersebut masih ada yang disediakan (Yani Brilyani Tavipah, kekurangannya, yaitu tidak 2006:118).

difoemulasikan secara setara antara sanksi pidana dan tindakan. Serta belum ada ancaman pidana minimum dam maksimum (Barda Nawawi Arief, 2000:60).

Tahap formulasi merupakan salah satu mata rantai dari perencanaan penegakan hukum, khususnya merupakan bagian dari proses konkretisasi pidana. Tahap ini merupakan tahap awal dan sekaligus merupakan landasan dari proses konkretisasi pidana berikutnya, yaitu tahap penerapan pidana dan tahap pelaksanaan pidana (Yani Brilyani Tavipah, 2006:118).

Penetapan jenis-jenis ancaman pidana di dalam hukum pidana, merupakan suatu bagian dari keseluruhan kebijakan kriminal. Hal ini dipandang penting karena disamping untuk menyediakan seperangkat sarana penaggulangan tindak pidana yang dapat dipergunakan hakim, sekaligus untuk membatasi kewenangannya dalam penggunaan sarana pidana lain, selain jenis-jenis pidana yang telah sanksi pidana apa yang dianggap paling baik untuk mencapai tujuan, stidaknya mendekati tujuan, tidak dapat dilepaskan dari persoalan pemilihan berbagai alternatif. Masalah pemilihan berbagai altrnatif. Untuk memperoleh pidana mana yang dianggap paling baik, paling tepat atau paling efektif meupakan masalah yang tidak mudah (Barda Nawawi Arief, 2000:60).

Penetapan jenis pidana oleh pembuat undang-undang antara lain dimaksudkan untuk menyediakan seperangkat sarana bagi penegak hukum dalam rangka menaggulangi kejahatan. Di samping itu dimaksudkan pula untuk membatasi penegak hukum dalam menggunakan sarana berupa pidana yang telah ditetapkan. Mereka tidak boleh menggunakan sarana pidana yang tidak lebih dulu ditetapkan oleh pembuat undang-undang. Dengan demikian jenis pidana yang dipilih dan ditetapkan oleh pembuat undangundang mengikat dan membatasi penegak hukum lainnya. 
Aliran modern menitikberatkan perhatiannya kepada orang yang melakukan tindak pidana dan pemberian pidana atau tindakan dimaksud untuk melindungi masyarakat terhadap bahaya yang ditimbulkan oleh pembuat (Barda Nawawi Arief, 2000:96).

Jika dihubungkan dengan keseluruhan sistem pemidanaan, penetapan sanksi pada hakikatnya merupakan kewenangan beberapa instansi dan dapat dianalogikan bahwa jatuhnya tahapan pemidanaan itu dari instansi yang satu ke instansi yang lainnya harus seperti air pegunungan yang mengalir tertib dan indah meskipun terdapat getarangetaran. Dalam konteks penerapan sanksi, getaran-getaran di sini sebagai contoh tentang kemungkinan terjadinya apa yang disebut dengan disparitas pidana (disparity of sentecing) (M. Sholehuddin, 2003:114).

Disparitas pidana tidak bisa ditiadakan sama sekali karena menyangkut persoalan sampai sejauh mana hal itu sebagai akibat yang tidak terelakkan dari kewajiban hakimuntuk mempertimbangkan seluruh elemen yang relevan dalam perkara individu tentang pemidanaanya. Sebab disparitas tidak secara otomatis mendatangkan kesenjangan yang tak adil. Demikian pula persamaan dalam pemidanaan tidak secara otomatis mendatangkan pidana yang tepa. Itulah yang menjadi dasar pembenaran pemberian pidana in concreto atau tahap yudikasi (M. Sholehuddin, 2003:116).

Saat ini sanksi yang diformulasikan dalam UndangUndang Nomor 11 Tahun 2008 adalah sanksi pidana, baik berupa pidana pokok maupun pidana tambahan. Sanksi tindakan tidak diformulasikan, serta ancaman pidana minimum dan maksimum tidak difoemulasikan juga. Berbeda halnya dengan Undang-Undang Korupsi, Narkotika, Terorisme yang mencantumkan ancaman pidana minimum dan maksimum.

Dilihat dari sanksi, UndangUndang Nomor 11 Tahun 2008 menggunakan single track system, karena tidak menempatkan sanksi tindakan setara dengan sanksi pidana. Sedangkan sistem sanksi dalam hukum pidana modern menermpatkan 
secara setara antara sanksi pidana dan sanksi tindakan atau yang disebut double track system.

Munculnya kritik menimbulkan respon positif untuk mencari bentukbentuk alternatif pidana penjara utamanya pidana penjara jangka pendek. Salah satu bentuk alternatif pidana penjara jangka pendek ialah merumuskan aturan pidana kerja sosial

Pidana kerja sosial ini dimunculkan dalam kerangka sebagai alternatif atau yang ditawarkan dari pidana perampasan kemerdekaan jangka pendek. Dengan demikian mengetahui penerapan pidana perampasan kemerdekaan khususnya pidana penjara jangka pendek dalam praktek menjadi sangat penting. Dari pengetahuan tersebut dapat terlihat sejauh mana pidana kerja sosial memiliki peluang untuk diterapkan sebagai alternatif pidana. Pidana kerja sosial dirasa penting untuk dikembangkan dalam pembaharuan hukum pidana di Indonesia yang merubah pandangan masyarakat mengenai pemidanaan yang berawal terhadap perampasan kemerdekaan bergerak maupun berkehendak beralih menjadi sanksi yang cukup menjanjikan yang memang mengikat seperti halnya sanksi pidana perampasan kemerdekaan tetapi tidak ditekankan kepada sanksi yang merampas kemerdekaan bagi seseorang.

Pidana kerja sosial mengandung unsur perlindugan masyarakat karena sudah ada tindakan pemidanaan yang nyata dari pemerintah, sesuai dengan nilai budaya bangasa Indonesia yaitu melakukan perbuatan yang bernilai sosial karena dilakukan di masyarakat yang tidak mengutamakan keuntungan. Selama menjalankan pidana, narapidana akan dibina dan dibimbing dari sisi pembentukan sikap dan tingkah lakunya (Muhammad Fajar Septiano, 2014:19).

Selain dari pidana kerja sosial yang menjadi alternatif pidana penjara. Sanksi tindakan juga sangat penting dalam hal ancaman yang dijatuhkan. Pentingnya sanksi tindakan diperlakukan sebagai sanksi mandiri, terkait erat dengan salah satu fungsi dasar setiap hukum pidana, yaitu mempengaruhi dan menuntun manusia melalui petunjuk dan 


$\begin{array}{lrr}\text { larangan deliknya } & \text { serta } \\ \text { mempengaruhinya lewat } & \text { sanksi } \\ \text { hukum pidana ataupun } & \text { cara } \\ \text { mendidik/pembinaan } & \text { (M. }\end{array}$

Sholehuddin, 2003:202).

Konsekuensi pandangan yang demikian menuntut secara tegas pemisahan jenis sanksi pidana dan tindakan serta keduanya ditempatkan setara dan diterapkan secara proporsional. Inilah makna terdalam dari konsep double track system (M.

Sholehuddin, 2003:203).

\section{C.SIMPULAN}

1. kebijakan formulasi sanksi pidana dalam menanggulangi tindak pidana siber dalam Undang-Undang Nomor 11 Tahun 2008 Jo. UndangUndang Nomor 19 Tahun 2016 belum dapat menekan angka kriminalitas, dikarenakan sanksi pidana dalam undang-undang ini masih menggunakan single track system hanya menggunakan sanksi pidana saja, seperti jenis pidana pokok yakni pidana penjara dan pidana denda, dengan ketentuan kumulatif-alternatif. Yang belum sesuai dengan tujuan pidana modern.

2. Kebijakan formulasi sanksi pidana Undang-Undang Nomor 19 Tahun 2016 di masa yang akan datang sehubungan dengan perkembangan kejahatan tindak pidana siber dalam masyarakat adalah dengan mengadopsi model sistem pemidanaan yang digunakan dalam Tindak Pidana Korupsi, Narkotika, Terorisme, serta konsep Rancangan Undang-Undang KUHP yaitu dengan diformulasikannya mengenai ketentuan sanksi pidana kerja sosial sebagai alternatif pidana penjara, tindakan dan ancaman minimum khsusus serta maksimum khusus.

\section{SARAN}

1. Perlu diperhatikan tahap-tahap kebijakan kriminal dimulai dari tahap formulasi, aplikasi, dan eksekusi. Dalam hal perbuatan dan sanksi pidana yang diancamkan, maka kriminalisasi dari perbuatan-perbuatan tertentu seharusnya sesuai 
dengan aspek-aspek tujuan pemidanaan dan sesuai dengan Pancasila dan Undang-Undang Dasar 1945.

2. Perlu direformulasi ketentuan mengenai sanksi pidana dengan ditambahkannya saksi tindakan, dan sanksi tindakan dapat berdiri sendiri dalam hal penjatuhan sanksi. Memformulasikan sanksi pidana keja sosial sebagai alternatif pengganti pidana penjara. Serta reformulasi ukuran ancaman pidana dari maksimal khusus, menjadi minimum dan maksimum.

\section{DAFTAR PUSTAKA}

\section{Barda Nawawi Arief, Kebijakan Legislatif dalam Penanggulangan Kejahatan dengan Pidana Penjara, Badan Penerbit Universitas Diponegoro, Semarang, 2000.}

, Kapita Selekta Hukum Pidana, Citra Aditya Bakti, Bandung, 2003.

Dini Dewi Heniarti, "Kejahatan Telematika", dalam Edi Setiadi (ed), Bunga Rampai Hukum Pidana, Universitas
Islam Bandung, Bandung, 2004.

H. Ahmad M. Ramli, Cyber Law dan HAKI dalam Sistem Hukum Indonesia, P.T. Refika Aditama, Bandung, 2004.

H. Zainuddin Ali, Hukum Pidana Islam, Sinar Grafika, Jakarta, 2009. , Metode Penelitian Hukum Sinar Grafika, Jakarta, 2009.

Henny Nuraeny, Tindak Pidana Perdagangan Orang: Kebijakan Hukum Pidana dan Pencegahannya, Sinar Grafika, Jakarta, 2013.

M. Sholehuddin, Sistem Sanksi Dalam Hukum Pidana, Ide Dasar Double Track System \& Implementasinya, Raja Grafindo Persada, Jakarta, 2003.

Russel Butarbutar, Kompilasi Hukum Pidana dan Aplikasinya di Masyarakat, Gramata Publishing, Jakarta.

Soerjono Soekanto, Efektivitas Hukum dan Peranan Sanksi, CV. Remadja Karya, Bandung, 1985.

Soerjono Soekanto dan Srim Mamudji, Penelitian Hukum Normatif, Suatu Tinjauan Singkat, Rajawali, Jakarta, 1985.

Sutan Remy Syahdeini, Kejahatan dan Tindak Pidana 
Komputer, P.T. Pustaka Utama Grafiti, Jakarta, 2009.

Winarno Surakhmad, Pengantar Penelitian Ilmiah; Dasar Metode Teknik, Tarsito, Bandung, 1994.
Undang-Undang Nomor 36 Tahun 1999 tentang Telekomunikasi.

UndangUndang Nomor 11 Tahun 2008 tentang Informasi dan Transaksi Elektronik.

Philemon Ginting, Kebijakan Penanggulangan Tindak Pidana Teknologi Informasi Melalui Hukum Pidana, Tesis, Universitas Diponegoro, Semarang, 2008.

Muhammad Fajar Septiano, Pidana Kerja Sosial Sebagai Alternatif Pidana Penjara Jangka Pendek, Fakultas Hukum Iniversitas Brawijaya, Artikel Ilmiah, Malang, 2014.

Yani Brilyani Tavipah, Kebijakan Formulasi Sanksi UndangUndang Nomor 31 Tahun 1999 Juncto UndangUndang Nomor 20 Tahun 2001 dalam Pemberantasan Tindak Pidana Korupsi, Tesis, Pascasarjana UNISBA, Bandung, 2006.

Undang-Undang Nomor 1 Tahun 1946 tentang Kitab UndangUndang Hukum Pidana. 